\title{
TTR
}

Traduction, terminologie, re?daction

\section{Michel Ballard, dir. Relations discursives et traduction. Lille, Presses Universitaires de Lille, 1995, 297 p.}

\section{Teymour Dowlatshahi}

Volume 9, numéro 2, 2e semestre 1996

Parcours de traduction

Pathways of Translation

URI : https://id.erudit.org/iderudit/037267ar

DOI : https://doi.org/10.7202/037267ar

Aller au sommaire du numéro

\section{Éditeur(s)}

Association canadienne de traductologie

ISSN

0835-8443 (imprimé)

1708-2188 (numérique)

Découvrir la revue

Citer ce compte rendu

Dowlatshahi, T. (1996). Compte rendu de [Michel Ballard, dir. Relations

discursives et traduction. Lille, Presses Universitaires de Lille, 1995, 297 p.] TTR,

9(2), 217-227. https://doi.org/10.7202/037267ar d'utilisation que vous pouvez consulter en ligne.

https://apropos.erudit.org/fr/usagers/politique-dutilisation/ 


\section{Michel Ballard, dir. Relations discursives et traduction. Lille, Presses Universitaires de Lille, 1995, 297 p.}

Some of the twelve contributors in Relations discursives et traduction are known to adhere to particular 'schools of thought' in Translation Studies, and some (such as Michel Ballard, who aiso compiled and edited the collection), do not represent any particular 'school' at all, but prefer to have an eclectic, all-embracing approach to the discipline. Notwithstanding this (and this has been the editor's laudable objective, in any case), the twelve contributions here are all united by the central theme reflected in the book's title: interlingual translation against a holistic backcloth of macrostructural, discourse-relatedperspectives, and more particularly, how source-text discoursal cohesion and thematic coherence are maintained at the macro-structural level of target-text (TT) discourse through the transformation, via the act of translation, of certain source-text (ST) linguistic elements (syntactic/morphological/ lexical/semantic) at the micro-structural level. 
Within the framework of the 'psychomechanical theory' presented in his Linguistique et traduction (1985), itself inspired by G. Guillaume's Langage et science du langage (1964), Georges Garnier, in a contribution entitled "Temps du passé et cohésion discursive," discusses the notion of anteriority within the verbal categories of grammatical tense and verbal aspect in French/English, with a view to establishing a general rule for 'translation equivalence'. The article begins with a recapitulation of the absolutely indispensable role attributed to verbal systems in the realization of language functions (e.g. Jakobson's six language functions : the referential; the emotive; the conative; the poetic; the phatic; the metalingual; Halliday's three language functions : the ideational, the interpersonal, the textual). Using Halliday's 'textual function' as the focus of attention, and the narrative verbal categories in both $\mathrm{TL}$ and SL dimensions as the means whereby this 'cohesive textuality' is to be achieved, Garnier attempts to demonstrate that, even if a speech-act may not be altogether grammatically coherent at the micro-structural level, intelligibility at the macro-structural level is nevertheless attained via what he terms 'reperes temporels'. It is precisely this temporal-aspectual framework he goes on to explore, this time by means of a substantial number of illustrative examples of grammatical utterances/speech-acts generated within the narrative continuum with which we are here exclusively concerned. Here he discusses the all-important temporal-spatial notion of 'aspect' by way of a number of concurrent binary oppositions that are analyzed in relation to an imaginary point ' $I$,' representing not only the fixed, immutable moment of actualization of the utterance or speech-act, but also that very actualization within the relative time- and spacecontinuum of an external reality that is in continual movement : 'immanence' versus 'transcendence'; 'imperfective' versus 'perfective'; 'posteriority' versus 'anteriority'; 'simple aspect' versus 'compound aspect'; 'aspect passé' versus 'aspect transpassé'. His tentative conclusion is that, where there is a preterite form in SL-English, the corresponding verb-form in TL-French will be the 'plus-que-parfait' (and the converse, namely that where there is a 'plus-que-parfait' form in SL-French, as in the case of the 'Madame Bovary' sentences analyzed, the corresponding verb-form in TL-English will be the 'préterit anglais'), and where, under certain syntactic and/or lexical conditions, SL-French uses the 'imparfait,' the corresponding TLEnglish verb-form will be past perfect (or pluperfect) progressive (or 
continuous) (although, erring on the side of caution, he stresses there is no hard-and-fast rule for translation equivalence, insisting that there will be conspicuous exceptions to this generalization, as evidenced by 'example (8)' (in fact this is a misprint : it should be 'example (10)': see p. 20)).

The contribution by Eugenia Gonzalez, entitled "Énonciation et formes syntaxiques, " likewise discussing temporal-aspectual factors within the verbal system, seeks to establish how discoursal cohesion is made possible intralingually for journalistic texts in French and Portuguese, and complements this by a contrastive study of interlingual translation (French/Portuguese) involving two basic types of discourse : narrative ('le récit') on the one hand, and reported speech/ 'indirect discourse' ('la citation') on the other. Within the latter category, however, a further sub-category is explored, where an extralinguistic/ cultural dimension of discourse complements the purely linguistic dimension. Proverbs, aphorisms, and epigrams provide a useful 'intertextual' resource for joumalists inclined towards oblique reference via rhetorical/stylistic devices such as paronomasia, polysemic homonymy, and chiasmus. And more generally, other extralinguistic/ cultural reference-points, such as the name of a famous personality, or the title of a well-known film (and creative portmanteau expressions often originate here), all have the ultimate purpose of addressing the "savoir encyclopédique d'un lecteur inséré dans une civilisation déterminée" (p. 50). Gonzalez draws a number of conclusions of great benefit for the translator with respect to the particular genre of the journalistic text. First, two kinds of narrative can be discerned in the language of journalism, within a threefold distribution of tenses across two temporal-aspectual dimensions (e.g. for French, époque présente: passé composé-présent-présent/futurversus époquepassée: plus-queparfait—imparfait/passé composé ou passé simple-conditionnel) : the narrative of the (imaginary) 'here-and-now' of the speech-situation (as evidenced in French by the present indicative tense, which functions here as an esoteric 'historic present'), from the vantage-point of the speaker ('enonciation' in French) on the one hand, and a narrative that (either for psychological and/or ideological reasons) involves a timedimension totally divorced from this. Second, the contemporary French press, as a general rule, appears to opt for the 'passe simple' when making certain value-judgements about events, otherwise the normal 
choice would be the 'imparfait' (whereas, for Portuguese, the author maintains, the relationship between tense and aspect is rather different). Third, the standard journalistic recourse to quotation and hearsay (within the context of 'indirect discourse') in the source-text will sometimes necessitate a compensatory strategy such as syntactic addition (e.g. adverbial temporal qualifiers) in the target-text. And finally, the language of journalism more often than not draws from extralinguistic/ semiotic repertoires (as embodied, for example, in the ingeniously creative deployment of portmanteau words), and consequently has the power to be both dynamic and innovative, thus assuring the continued synchronic evolution of Saussurean 'langue' via the Saussurean 'parole' of the receptor-audience. (There is a glaring typographical omission here: in the 'roi Juan Carlos' example given on page 42, the 'déictique situationnel' 'lundi' is missing).

Temporality is again the focus of attention in the next contribution, entitled "Quelques indicateurs de continuité dans le discours de vulgarisation scientifique", by Anne-MarieLoffer-Laurian. However, rather than focusing on the role of the verb, the author attempts to show how temporal continuity is maintained within discourse (and this time the text-type being discussed is 'popularized' scientific literature 'de haut niveau,' rather than 'le discours scientifique au sens strict') via the strategic introduction of certain qualifying linguistic elements (these are variously described as 'relations de rappel,' or 'éléments de liaison,' or 'éléments/indicateursde continuite') on the syntagmatic axis. Deictic and anaphoric elements (e.g. the demonstrative adjective) act as "garde-fous du discours" (p. 57), thus ensuring that the discourse in question is confined 'a l'interieur des limites voulues'. Emphatic markers (e.g. 'en fait' or 'c'est ... que' as emphatic qualifiers) àso contribute towards discoursal cohesion. Punctuation marks (such as commas and brackets) allow certain thematic aspects to be subsumed under others. Link-words acting as antithetical qualifiers (such as the isolated lexemes 'helas' and 'pourtant,' or the syntagm 'contrairement a ...,' or the subordinating conjunction 'bien que ...') not only reinforce the cohesion of linguistic elements via temporal continuity, but also contribute to the dialectic interaction of [thesis + antithesis $\Rightarrow$ synthesis] at the thematic/ conceptual level, during the process of scientific deliberation (apart from this, there are the 'logical' link-words, or 'éléments de liaisons 
habituels,' such as 'or,' 'mais,' 'tout au plus,' which ensure coherence at the level of thought-content). Of course, as isomorphic equivalence between natural languages is the exception rather than the rule, these temporal-spatial linking devices will, generally speaking, be different for the two languages studied (French and Spanish), involving syntactic expansion here for the SL, lexical ellipsis there for the TL; an alleged propensity for 'affirmation' in Spanish (as reflected by its linguistic structure) versus 'negation' in French; a logical-systematic progression of thought reflected in the ST French examples given, its apparent paucity in the corresponding TT Spanish examples; and so on. A subgenre is also discussed : 'la vulgarisation de type grand public,' as opposed to 'la vulgarisation pour public averti'. The continuity in question is maintained by means of an informal, conversational style that concentrates on fully exploiting the emotive/expressive function of language.

Douglas A. Kibbee, in a French/English contrastive analysis entitled "Assertion/atténuation, subjectivité/objectivité en anglais et en français : 'seem/sembler," discusses the 'assertive' and 'attenuative' aspects of the respective SL verbs 'seem' and 'be' (usual TL equivalents : 'sembler'/'être'), using 19 French translations of Lewis Carroll's Alice in Wonderland as its investigative corpus. Out of 697 potential TT possibilities for the ST verb 'seem' (which has, in English, an "effet atténuant puisqu'il souligne la subjectivité de ce qui suit, en marquant un manque de certitude ou simplement un manque de précision chez l'observateur," p. 74), nearly 4 out of 10 attempt to achieve this attenuative effect by opting for 'sembler,' with another 2 out of 10 preferring 'paraître,' and a further 2 out of 10 not attempting to render this attenuative factor at all. The author proceeds to investigate four different areas of concern regarding semantic elements and/or syntactic structures and/or lexical choices : first, contexts where an equivalent TL verb (such as 'sembler,' 'paraître,' 'avoir l'air') is used (the conclusion here being that "les conditions pour l'enploi de sembler, paraître, avoir l'air sont plus restreintes que celles en anglais pour l'emploi de seem," p. 79); second, situations where the SL attenuative factor is ignored (the conclusion here being that "l'absence de l'hésitation résultant du contraste entre te réel et l'attendu favorise l'absence du verbe d'attenuation," p. 80); third, translational options involving the greatest variation in TT solutions (one particular ST 
sentence is here analyzed in depth, with 19 TT solutions); and finally, those paradoxical situations (in fact a surprising 98 examples were listed) where a TT equivalent for the SL verb 'seem,' namely 'sembler,' is provided, despite the conspicuous absence of 'seem' in every $S T$ example (and the conclusion here is that French 'sembler' covers an appreciably greater semantic range than English 'seem, 'in terms of both sensual and cognitive experience). The findings here, as far as the English verb 'seem' and its French equivalents are concerned, suggest that French and English have, in keeping with the Sapir-Whorf hypothesis, differing visions of the world, and furthermore appear to imply that the 'linguistic universal' so dear to linguistic theory is at best an illusory concept.

The next contribution, "Relations discursives plurivalentes et traduction," by Ronald Landheer, questions the validity for literary translation of the 'interpretative' theory of translation as formulated by Séleskovitch/Lederer (concentrating on ST 'message' rather than ST 'linguistic realization'), explaining how certainmicro-structuralelements within a text (such as the polysemic lexeme 'feu' in the famous utterance from Racine's Andromaque, "Bralé de plus de feux que je n'en allumai") have plurivalent function at the macrostructural level of discourse. The synonymous terms Landheer uses for this phenomenon are 'plurivalence textuelle,' 'plurivocité textuelle,' 'ambivalence textuelle,' 'polyisotopie,' and 'le double jeu sur le code.' The translational strategy one might use to realize translation equivalence (involving semantic-pragmatic considerations which would establish an 'équilibre textuel' macrostructurally, via certain 'compensatory strategies' facilitating 'functional equivalence,' rather than an 'equivalence locale' microstructurally, where the focus is on localized lexical content/grammatical form : in other words, "on ne traduit pas des mots, on traduit des textes," p. 96) will depend on whether this semantic bifurcation or "plurivalent ambiguity' on the part of the ST author is conscious and intentional (as in the Racinian example cited, and the other examples given throughout this article), or merely unwanted and accidental. If the former obtains, the translator must attempt to render this 'plurivocite' or 'effet plurivalent' in the targettext (often the result of ST homonymic and polysemic wordplay : the classic example given here is "Is life worth living ? It depends upon the liver, " p. 95), and cannot be permitted to have recourse to the oft- 
encountered excuse that a particular word or phrase is 'untranslatable' ("[...] il importe de se défaire du parti-pris qui veut qu'une plurivocité textuelle soit normalement intraduisible," p. 103). In the case of the latter, however, the translator can omit the ambiguous ST linguistic element altogether, or at least mitigate its effect in the TT. There is also an impressive theoretical discussion at the heart of the article, the exclusive purpose of which is to demolish the 'untranslatability hypothesis' by illustrating how 'creative' translational solutions for apparently impenetrableSL rhetorical/stylisticdevices, such as puns, can be made possible by means of 'compensatory strategies' within a functional-communicative and pragmatic-semantic perspective.

"L'Anaphorisation des noms de personnes en anglais et en français," by John D. Gallagher, analyzes the interlinguistic divergence between French and English with regard to anaphoric (as well as cataphoric) reference as a cohesive device at the suprasentential level of discourse. Gallagher's starting-point is that English tends to prefer pronominalization, whereas it appears that French is rather partial to the retention of proper names. Using samples of literary narrative from Simenon, Colette, Atwood, and others, he then proceeds to develop this by illustrating what he terms the 'anaphore stricte' on the one hand (where TL. French will opt for the proper noun in order to preserve the original ST discoursal cohesion), and the 'anaphore non-stricte' on the other (where TL French will use the same strategy, but only optionally). Finally, he goes on to delineate a number of problem-areas the translator might encounter with regard to this phenomenon.

Claude Demanuelli, in "la Virgule en question," regretfully acknowledging that not enough attention has been paid heretofore to the phenomenon of the punctuation mark (the 'poncteme'), discusses the diverse functions of the comma (one element of the 'poncteme' family) within discourse analysis. According to Demanuelli, not enough attention has been paid hitherto by translation theorists and linguists to this linguistic and discoursal phenomenon. These functions, which necessarily operate as cohesive facilitators, relate either to the syntacticsemanticaspects of the speech-act, or its stylistic-situational aspects and, to a lesser extent, its prosodic/intonational features (or perhaps to some combination of these). The discussion first of all centres on intralingual applications of the comma in French and English. Then follows a 
contrastive interlingual analysis. Demanuelli starts off from the premise (established by previous studies) that French tends to deploy commas much more frequently than English does, and then proceeds to corroborate this by way of a contrastive interlingual analysis (via literary texts) dealing with two areas of punctuation: the 'cas de servitude,' where the comma is an absolute requirement; and the 'options stylistiques, ' where the deployment of this grammatical/stylistic device will depend on the translator's interpretation (creative or otherwise, by way of what Demanuelli terms the latter's 'libre-arbitre') of the ST author's stylistic/rhetorical motivation.

Matthew MacNamara, in "Some French intersentence connectors in a journalistic corpus and their English translations," examining a corpus of ST French texts taken from the French weekly, $L$ 'Express, and their respective translations into TL English, highlights the role of 'adversative intersentence connectors' (such as 'mais,' 'pourtant,' 'cependant, 'tout de même,' 'encore faut-il,' in French; and 'but,' 'however,' 'nevertheless,' 'admittedly,' 'as a matter of fact,' in English) within the context of theme/rheme (old information/new information) focalization, due consideration having been given, of course, to various paradigmatic and syntagmatic factors. MacNamara concludes that SL French 'mais' is, more often than not, translated in TL English by something other than 'but'; that it is the 'argumentative focus' within the theme/rheme element of discourse that determines how the ST interconnector will be translated; and finally, that these antithetical SL 'connectors' appear to be a stylistic specificity characteristic of one particular text-type, that of the French journalistic text.

Jean-Claude Souesme, in "BUT,' marqueur de passage de frontière et ses traductions en français," provides a thorough and comprehensive analysis of the English SL lexeme 'but' (contemporary usage, as well as literary and/or archaic usage), and its surprisingly considerable range of semantic values (depending on the speechsituation) not only as an adversative connector (e.g. but='mais,' but='cependant'), but also (and especially) as an adverbial qualifier (e.g. but $=$ 'tout simplement'; but = 'donc'; all but= 'presque'). This is examined contrastively by means of a corresponding medley of TL French equivalents. In all cases, the SL lexeme 'but' is the invariable 
constant in all ST speech-acts illustrated. Two theoretical concepts of some significance for Souesme's analysis here are the 'domaine notionnel' and the 'passage de frontière,' as formulated by A. Culioli.

Again examining translational solutions with regard to the English SL lexeme 'but,' Myriam Salama-Carr, in "BUT/mais' dans l'analyse du discours. Notes sur la traduction de 'but," focuses exclusively on the diverse functions of this lexeme as an adversative coordinating conjunction, with its corresponding standard equivalents in TL French (generally 'mais,' and sometimes 'pourtant,' or 'cependant'). Two sets of French-TT examples from two different ST-English 'genres' (in the one case, The UNESCO Courier; a John Arden play in the other), where the translational strategies deployed for each appear to be diametrically opposed (the former using the 'interpretative' approach modelled after Séleskovitch/Lederer, hence varied renderings for 'but,' with the latter using a very 'literal' approach, hence invariably 'mais' for 'but'), are exarnined contrastively with their corresponding source-texts. The objective is to establish to what extent the structural cohesion and thematic coherence of the ST have been preserved, and to what extent not. In conclusion, the author recommends that the standard renderings for 'but' as an adversative connector (i.e. 'mais,' 'pourtant,' 'cependant') be deployed in French, unless various discoursal factors intervene to modify this normative translational choice.

The penultimate contribution, "l'Effacement des connecteurs adversatifs et concessifs en français moderne," by John D. Gallagher, on the face of it, deals with a problem-area for translators akin to the ones encountered in the preceding two contributions, but in actual fact concentrates on a stumbling-block of a totally different order. The article begins with an intralingual study (both at the localized level of the sentence and the suprasentential level of discourse) of the variety of ways in which the adversative and concessive connector ('mais,' pourtant,' 'cependant,' 'toutefois') is consciously avoided in Modern French by means of the 'style coupe' (hence the absent and/or hidden 'connecteur zéro'). In order to retain this antithetical function, other linguistic devices appear to be used instead (such as the juxtaposition of adversative and/or contrasting elements via the use of punctuation marks, namely the semi-colon, or the comma; or the use of certain other link-words/-phrases, such as the coordinating conjunction 'et,' or the 
relative marker 'ce qui,' or the emphatic pronoun 'lui,' 'eux,' etc.). Furthermore, certain modern French writers (e.g. André Maurois), it seems, have a stylistically-motivated predilection for this 'connecteur zéro,' but it is stressed that the frequency with which the latter is used will be determined in some measure by the French-language author's 'idiolect' or personal literary style, rather than by the priorities established by Saussurean 'langue' (in which case the conclusion that French tends to be more 'implicit,' and English and German more 'explicit,' would be more than merely tentative here). The article then proceeds to discuss how these SL 'connecteurs zéro' are tackled interlingually, when translated into English and German respectively (a large corpus of literary examples is given). Generally speaking, for any given ST French 'connecteur zéro' English and German will, as a matter of course, invariably opt for the surface-realization of the 'jonctif antinomique' or antithetical conjunction, as evidenced by the TT English/German examples given (hence giving but/yet for English, jedoch/aber/doch/hingegen/allerdings for German).

And finally, "la Traduction de la conjonction 'and' en français," by Michel Ballard, which is by far the most voluminous contribution, seeks to establish certain fundamental tendenciesgoverning the behaviour of a 'translational unit' that has the SL English coordinating conjunction 'and' as its nucleus (an example of one such tendency is 'effacement' : when English-SL 'and' as a connector of non-verbal elements occurs, say, three times in succession, French-TL. will only translate the very last connector). Hand in hand with this, a taxonomy at the microstructural level is provided of the various kinds of 'traduction oblique' (involving reformulation or restructuring, often via 'transformation' of the original ST surface structure e.g. recourse to the gerundive in French for 'coordination interpropositionnelle' in English in order to preserve the 'function' of simultaneity of action) that this SL link-word will generate, and this is compared in terms of frequency with the various manifestations of 'traduction litterale' (involving close reproduction of the original ST structure, e.g. the 'calque structural'). Several theoretical perspectives are critically examined (Vinay/Darbelnet, Tesnière, Mounin), following which Balland exhaustively delineates, and with the benefit of copious contrastive/interlingual examples from English literary texts (TT=French), the various semantic actualizations of this 'marqueur de 
relation' in the speech-act, and its corresponding 'functions' on the syntagmatic and paradigmatic axes. The latter are apparently threefold: first, 'and' provides new information at the level of discourse; second, 'and' can act as a temporal indicator (e.g. consecutive/simultaneous action); third, 'and' can suggest result, goal, contrast/opposition, causality, and so on. Thus, only when the 'function' of the ST translational unit has been filly determined can a suitable TT translational solution be negotiated. Of course, this will also depend on the translator's (subjective) decisions regarding translational strategies (e.g. 'restructuration' versus 'calque'), as evidenced by the comparison, toward the end of this study, of three TT renderings of ST examples taken from Carroll's Alice in Wonderland. Some of the terminology used here (such as 'relation interpropositionnelle,' 'relation interprocès,' ' 'and' interphrastique,' 'and' prédicatif'), as the author himself acknowledges, has been borrowed from Guillemin-Flescher's Syntaxe comparée du français de l'anglais : Problemes de traduction (1981).

Teymour Dowlatshahi University of Toronto 